\title{
Wielka Brytania w interwencji zbrojnej w Libii w 2011 r.
}

\begin{abstract}
Abstrakt: Artykuł dotyczy problematyki uczestnictwa Wielkiej Brytanii w interwencji zbrojnej w Libii w 2011 r. Składa się on z pięciu części. Dwie pierwsze części obejmują przyczyny zaangażowania się Wielkiej Brytanii w interwencję zbrojną w Libii i jej przygotowania do tej interwencji. W trzeciej części omówiono udział brytyjskich sił zbrojnych w operacji NATO „Unified Protector”, a w czwartej - konsekwencje interwencji zbrojnej w Libii i uczestnictwa w niej Wielkiej Brytanii. Artykuł zamyka podsumowanie i perspektywy dalszego zaangażowania Wielkiej Brytanii w Libii.
\end{abstract}

Słow a klucz owe: Wielka Brytania, Libia, interwencja zbrojna, operacja humanitarna.

Abstract: The article deals with the problem of Britain's engagement in a military intervention in Libya in 2011. It is composed of five parts; the two first describe the reasons for the British involvement in a military intervention in Libya and their preparations. Part three discusses the participation of the British armed forces in the NATO "Unified Protector" operation, while part four presents the consequences of the military intervention in Libya and the British involvement. The article ends with a conclusion and prospects of the future engagement of Great Britain in Libya.

Keyw ords: Great Britain, Libya, military intervention, humanitarian operation.

\section{Przyczyny zaangażowania się Wielkiej Brytanii w interwencję zbrojną w Libii}

Przekonanie władz brytyjskich co do konieczności podjęcia akcji zbrojnej w Libii wynikało przede wszystkim z przesłanek humanitarnych ${ }^{1}$. W społeczeństwie

${ }^{1}$ G. Gogowski, Przywództwo bez przekonania. Brytyjska postawa wobec konfliktu w Libii, 15 XI 2011, http://www.psz.pl/127-unia-europejska/grzegorz-gogowski-przywodztwo-bez-przekonania-brytyjska-postawa-wobec-konfliktu-w-libii (dostęp: 6 IX 2017). 
brytyjskim żywa była pamięć o zbrodniach na ludności cywilnej popełnionych w latach dziewięćdziesiątych XX w. na Bałkanach i w Rwandzie. Setki tysięcy, a nawet miliony ludzi dałoby się uratować w trakcie tych i innych konfliktów zbrojnych prowadzonych w różnych częściach świata, gdyby społeczność międzynarodowa nie zwlekała z podjęciem zdecydowanych działań zaradczych. Szczególna odpowiedzialność za te tragiczne wydarzenia spoczywała na Wielkiej Brytanii i innych stałych członkach Organizacji Narodów Zjednoczonych (ONZ). W związku z tym rząd Davida Camerona nie chciał dopuścić do popełnienia podobnego błędu w przypadku Libii. Zadeklarował on gotowość do wzięcia udziału w interwencji zbrojnej w tym państwie, by, jak to określił za pośrednictwem swojego rzecznika, przerwać „rzeź wśród cywilów”2. W ten sposób władze brytyjskie chciały doprowadzić do ograniczenia liczby ofiar wśród ludności cywilnej i ugrupowań rebelianckich ze strony wojsk rządowych Muammara Kaddafiego.

Aby przekonać Brytyjczyków do zasadności interwencji zbrojnej w Libii, rząd Wielkiej Brytanii przedstawiał krajowej opinii publicznej argumenty dotyczace potencjalnego wpływu tego kryzysu na własne bezpieczeństwo narodowe ${ }^{3}$. Łączenie ówcześnie kryzysu libijskiego z bezpieczeństwem Wielkiej Brytanii nie było zupełnie oderwane od realiów międzynarodowych. Zarazem wpływ ten wydawał się mieć charakter jedynie pośredni. Niestabilność państwa znajdującego się w bliskim sasiedztwie Europy stwarzała ryzyko rozprzestrzeniania się negatywnych zjawisk na Stary Kontynent, w tym także na Wyspy Brytyjskie. Europie potencjalnie zagrażały wzmożony ruch uchodźczy, rozwój przestępczości zorganizowanej, w tym nielegalnego handlu bronią i ludźmi, wzrost tendencji fundamentalistycznych i rozprzestrzenianie się przestępczości terrorystycznej czy nawet piractwo morskie, głównie na Morzu Śródziemnym. Upadek państwowości w Libii faktycznie doprowadził do dynamicznego rozwoju wielu powyższych zjawisk. Tym samym negatywnie wpłyną na bezpieczeństwo Europy, a w tym Wielkiej Brytanii.

Wśród powodów zaangażowania się Wielkiej Brytanii w rozwiązanie kryzysu w Libii warto zwrócić uwagę na zjawisko terroryzmu międzynarodowego. $\mathrm{Z}$ jednej strony Libia przez lata propagowała ten nielegalny proceder, a z drugiej ofiarami terroryzmu niejednokrotnie byli Brytyjczycy. W latach osiemdziesiatych XX w. Libię, zaraz po Iranie, społeczność międzynarodowa uznawała za najbardziej wydatnie wspierająca terroryzm międzynarodowy. W tym okresie rocznie szkoliła ona średnio 8 tys. terrorystów i współfinansowała szereg zamachów w różnych częściach świata, głównie w Europie i na Bliskim Wschodzie.

\footnotetext{
${ }^{2}$ M. Kozłowska, Kadafi nie ustapi, ONZ nie ustapi Kadafiemu, „Polityka”, 19 III 2011, http:// www.polityka.pl/tygodnikpolityka/swiat/1514128,1,libia-pierwsza-zbrojna-interwencja-zachodu.read (dostęp: 6 IX 2017).

${ }^{3}$ G. Gogowski, op. cit.

${ }_{4}^{4}$ T.R. Phinney, Airpower versus Terrorism. Three Case Studies, Montgomery 2003, s. 13.
} 
15 IV 1986 r. Stany Zjednoczone przeprowadziły operację powietrzna „El Dorado Canyon", polegająca na zbombardowaniu obiektów wojskowych w Trypolisie i Bengazi. Był to odwet za dokonany 10 dni wcześniej zamach bombowy na dyskotekę La Belle w Zachodnim Berlinie. Odpowiedzialnością za zamach, w którym zginęło 2 amerykańskich żołnierzy, Waszyngton obarczył władze libijskie ${ }^{5}$. Był to już kolejny zamach wiązany z libijskimi kręgami rządowymi, w którym zginęli Amerykanie. Jeden z celów amerykańskiej operacji powietrznej stanowiła siedziba Kaddafiego, jednak dyktator unikną śmierci. Według przedstawicieli rządu libijskiego podczas bombardowań zginęła jednak adoptowana przez niego córka Hanna, a 2 jego synów odniosło rany ${ }^{6}$.

Premier Margaret Thatcher (V 1979 - XI 1990) była jedyna europejska przywódczynia, która poparła militarne plany wobec Libii ówczesnej administracji prezydenta Ronalda Reagana (I 1981 - I 1989). Kierowany przez nią rząd zgodził się na realizację przez Amerykanów lotów bojowych na Libię z wykorzystaniem lotnisk Królewskich Sił Powietrznych (Royal Air Force $-\mathrm{RAF})^{7}$. Głównym powodem wsparcia Amerykanów przez Brytyjczyków w tej operacji bojowej była potrzeba umacniania „specjalnych relacji” $\mathrm{z}$ supermocarstwem. Ponadto władze w Londynie posiadały sprawdzone informacje na temat sponsorowania przez libijski reżim Irlandzkiej Armii Republikańskiej (Irish Republican Army - IRA), która organizowała zamachy terrorystyczne na terytorium Wielkiej Brytanii ${ }^{8}$. W odwecie za bombardowania Libijczycy przeprowadzili 21 XII 1988 r. nad Lockerbie w Szkocji zamach na lot 103 linii Pan American World Airways z Londynu do Nowego Jorku. Zginęło wówczas 270 osób, w tym 189 obywateli Stanów Zjednoczonych i 43 obywateli Wielkiej Brytanii ${ }^{9}$. W 2001 r. na karę co najmniej 27 lat więzienia skazany został Libijczyk Abdelbaset al-Megrahi ${ }^{10}$. Szkoccy śledczy stwierdzili ponadto, że w organizacji zamachu brały udział również inne osoby. W związku z tym po odsunięciu od władzy Kaddafiego rząd brytyjski zwrócił się do Przejśsiowej Rady Narodowej Libii (National Transitional Council of Libya - NTC) o pomoc w poszukiwaniu osób współdziałających z Megrahim ${ }^{11}$.

51986 U.S. bombs Libya, http://www.history.com/this-day-in-history/u-s-bombs-libya (dostęp: 9 IX 2017).

6 Ibidem.

${ }^{7}$ A.P. Dobson, Anglo-American Relations in the Twentieth Century. Of friendship, conflict and the rise and decline of superpowers, London-New York 1995, s. 160-161.

${ }^{8}$ D. Brown, Britain and the Politics of Counter-Terrorism: The 2002 New Chapter and Beyond, w: The Development of British Defence Policy. Blair, Brown and Beyond, red. D. Brown, London-New York 2010, s. 89.

9 J. Greenspan, Remembering the 1988 Lockerbie Bombing, 20 XII 2013, http://www.history. com/news/remembering-the-1988-lockerbie-bombing (dostęp: 6 IX 2017).

10 B. Butalia, The Assassin's Mace, Bloomington 2011, s. 57.

11 PAP, Tak działaja porzadne państwa. Po 23 latach szkoccy prokuratorzy nadal szukaja informacji $w$ sprawie zamachu na samolot PanAm nad Lockerbie, 27 IX 2011, https:// 
O zaangażowaniu wojskowym Wielkiej Brytanii w Libii w 2011 r. zdecydowała również sytuacja polityczno-militarna w tym kraju. Według Londynu ruch rebeliancki okazał się na tyle silny i zjednoczony, że upadek reżimu Kaddafiego był tylko kwestia czasu. 21 lutego zbrojna opozycja zajęła Bengazi, które stało się siedzibą władz powstańczych. Na początku marca rebelianci kontrolowali praktycznie całą wschodnią część kraju i przygotowywali się do marszu na Trypolis. 6 marca rozpoczęła się jednak zdecydowana i skuteczna ofensywa wojsk rządowych, która doprowadziła do odbicia z rąk rebeliantów wielu miast. Mimo to władze brytyjskie były przekonane, że rebelianci prędzej czy później stworzą nowy rząd w Libii. W przeświadczeniu tym utwierdzały je zbrodnie popełniane przez libijski reżim, które antagonizowały coraz większe rzesze społeczeństwa. Jeszcze kilka miesięcy przed obaleniem Kaddafiego Wielka Brytania, podobnie jak Francja, uznała opozycyjna NTC za prawowita reprezentację państwa libijskiego. Wynikało to z faktu, że dostrzeżono jej zwiększająca się legitymację, poszerzane kompetencje na kontrolowanych terenach i wzrastające poparcie społeczne. Uznanie przez Wielka Brytanię zorganizowanej grupy zbrojnej w Libii za ,jedyną legalna władzę" znaczyło, że według Londynu powinna ona automatycznie przejąć kompetencje rządu ${ }^{12}$.

Pewien pośredni wpływ na decyzję Londynu w kwestii Libii miały wydarzenia historyczne związane z dojściem Libii do niepodległości i wynikające z nich poczucie współodpowiedzialności Brytyjczyków za to państwo. Od 1943 do $1951 \mathrm{r}$. Libia znajdowała się pod okupacją aliantów z okresu II wojny światowej. Wielka Brytania administrowała dwie wcześniejsze włoskie prowincje w Libii - Trypolitanię na północnym zachodzie i Cyrenajkę na wschodzie, a Francuzi - Fazzan na południowym zachodzie. W 1947 r. ostatecznie praw do Libii zrzekły się Włochy. Związek Radziecki obawiał się, że w tej sytuacji Wielka Brytania będzie próbowała przekształcić Libię w „nowy Egipt”, czyli państwo formalnie niepodległe, jednak w praktyce pod okupacja brytyjska. Brytyjczycy faktycznie domagali się „specjalnych strategicznych praw” w Libii. Mieli m.in. nadzieję na dodatkowe porty morskie na Morzu Śródziemnym, zlokalizowane u wybrzeży tego państwa ${ }^{13}$. Ostatecznie 24 XII $1951 \mathrm{r}$. została jednak ogłoszona niepodległość Libii. Przez prawie dwie pierwsze dekady suwerenności państwowej była ona monarchią i funkcjonowała jako Zjednoczone Królestwo Libii (United Kingdom of Libya). 1 IX 1969 r. grupa oficerów pod przywództwem płk. Kaddafiego obaliła w drodze zamachu stanu króla

wpolityce.pl/polityka/119256-tak-dzialaja-porzadne-panstwa-po-23-latach-szkoccy-prokuratorzy-nadal-szukaja-informacji-w-sprawie-zamachu-na-samolot-panam-nad-lockerbie (dostęp: 9 IX 2017).

12 P. Rowe, Legal Accountability and Britain's Wars 2000-2015, London-New York 2016, s. $45-47$.

${ }^{13}$ J. Callaghan, The Labour Party and Foreign Policy. A History, London-New York 2007, s. $166,168$. 
Idrisa I. Pod hasłami „wolności, socjalizmu i jedności” ustanowiono Arabska Republikę Libii (Libyan Arab Republic), w której władzę dyktatorską skupił w swoich rękach przywódca puczu. Nowa władza sprzymierzyła się z państwami bloku wschodniego przeciwko „imperialnemu Zachodowi”.

Kolejnym pośrednim powodem zaangażowania były relatywnie bliskie relacje gospodarcze między Wielką Brytanią i Libią, przede wszystkim w sektorze produkcji ropy naftowej. Warto przypomnieć, że Libia wydatnie przyczyniła się do kryzysu energetycznego z połowy lat siedemdziesiątych XX w., godzącego przede wszystkim w interesy państw Europy Zachodniej. Jeszcze przed kryzysem naftowym rząd Libii postawił ultimatum zagranicznym koncernom wydobywczym, zmuszając je do zgody na przejęcie ich przez państwo libijskie. Alternatywą było całkowite zaprzestanie eksportu ropy z Libii na Zachód. Po wybuchu wojny Jom Kippur w październiku 1973 r., gdy administracja prezydenta Richarda Nixona (I 1969 - VIII 1974) zapowiedziała pomoc finansową dla Izraela, państwa arabskie skupione w Organizacji Krajów Eksportujących Ropę Naftowa (Organization of the Petroleum Exporting Countries - OPEC) zdecydowały się zastosować szantaż naftowy. Libia jako pierwsza ogłosiła embargo na dostawy ropy naftowej do Stanów Zjednoczonych, a inne państwa przyłączyły się do tej inicjatywy. Państwa OPEC ograniczyły wydobycie surowca i podniosły jego cenę o 70\%. Całościowo w wyniku kryzysu ceny ropy na rynkach światowych wzrosły z 3 do 12 dol. za baryłkę. Dla Wielkiej Brytanii był to poważny problem, ponieważ libijska produkcja ropy naftowej zaspokajała ówcześnie ok. 14\% zapotrzebowania tego państwa $\mathrm{w}$ surowiec ${ }^{14}$. Kolejny dotkliwy wzrost cen ropy naftowej miał miejsce w 1979 r., w trakcie tzw. drugiego kryzysu naftowego. Z powodu m.in. działań OPEC cena ropy naftowej w ciagu 12 miesięcy wzrosła z 15 do 39 dol. za baryłkę. Po 1988 r. w Libii rozpoczęła się ekonomiczna i w pewnym stopniu również polityczna liberalizacja. Stopniowo Libia wychodziła z międzynarodowej izolacji, a spośród państw europejskich nawiązała bliższe stosunki właśnie z Wielką Brytanią i Francją. Warto wspomnieć, że w 2009 r. zwolniono z więzienia w Szkocji i przekazano do Libii oskarżonego o organizację zamachu nad Lockerbie Megrahiego. Oficjalnie uwolnienie nastapiło ze względów humanitarnych, po stwierdzeniu u niego raka prostaty. Prasa amerykańska i brytyjska łączyły jednak tę decyzję z podpisaniem kontraktu naftowego między BP p.l.c. a Libya's National Oil Company ${ }^{15}$. Miał to być ukłon ze strony rządu premiera Gordona Browna (VI 2007 - V 2010) w kierunku zabiegajacego od lat o to zwolnienie Kaddafiego ${ }^{16}$.

${ }^{14} \mathrm{~S}$. Wall, The Official History of Britain and the European Community, t. II: From Rejection to Referendum, 1963-1975, London-New York 2013, s. 474.

15 J. Dumbrell, Personal diplomacy: Relations between prime ministers and presidents, w: Anglo-American Relations. Contemporary perspectives, red. A.P. Dobson, S. Marsh, London-New York 2013, s. 98.

16 B. Butalia, op. cit., s. 57. 
Wielka Brytania nie zamierzała rezygnować ze współpracy gospodarczej z Libia, a wręcz przeciwnie, była zainteresowana jej intensyfikacja. Premier Cameron chciał demonstracyjnie zdystansować się od przyjaznej polityki poprzedników wobec reżimu Kaddafiego - tj. Tony'ego Blaira (V 1997 - VI 2007) i Browna. Najbardziej dobitnym tego przejawem było militarne wsparcie libijskiej opozycji zbrojnej. Rząd brytyjski zdecydował się wesprzeć zbrojnie rebeliantów, wierząc, że po obaleniu libijskiego dyktatora to ich przywódcy będa piastować najwyższe stanowiska w państwie. Potencjalnie miało to dać Wielkiej Brytanii doskonała pozycję negocjacyjna podczas zabiegania o kontrakty gospodarcze w Libii. Tradycyjnie Brytyjczycy najbardziej zainteresowani byli eksploatacją tamtejszych złóż naftowych. Potencjalnie mogliby stać się również jednym z głównych dostawców uzbrojenia i sprzętu dla tworzonych od podstaw libijskich sił bezpieczeństwa, w tym głównie armii. Nie musieliby się niepokoić o płatności za dostarczany ekwipunek ze względu na znaczne zyski, jakie nowe władze mogłyby czerpać ze sprzedaży ropy naftowej. Szybkie odtworzenie pełnych mocy produkcyjnych było możliwe, ponieważ instalacje naftowe $\mathrm{w}$ niewielkim stopniu ucierpiały z powodu trwajacej w kraju rebelii. Ponadto zakładali, że Libia otrzyma znaczne środki na odbudowę i rozwój od społeczności międzynarodowej. Również brytyjskie firmy z sektora budowlanego mogłyby być uprzywilejowane w pozyskiwaniu kontraktów na odbudowę i modernizację Libii.

Dodatkowo do podjęcia przez rząd Camerona decyzji o zaangażowaniu się Wielkiej Brytanii w konflikt w Libii być może przyczyniły się czynniki o charakterze stricte wewnętrznym. Motywem takim mogła być próba odwrócenia uwagi krajowej opinii publicznej od zapowiadanych głębokich cięć w wydatkach publicznych. W październiku 2010 r. brytyjski minister finansów George Osborne (V 2010 - VII 2016) przedstawił program najgłębszych od 60 lat cięć budżetowych. Miały one ograniczyć koszty poszczególnych departamentów średnio o 19\% i w ciagu 4 lat pozwolić zaoszczędzić kwotę 83 mld funtów. Plan zakładał m.in. radykalną redukcję zasiłków z opieki społecznej, podniesienie wieku emerytalnego do 66 lat i likwidację setek tysięcy miejsc pracy w sektorze publicznym ${ }^{17}$. Zaangażowanie Wielkiej Brytanii w działania wojenne w Libii potencjalnie mogło przenieść punkt ciężkości zainteresowania mediów i opinii publicznej na wydarzenia poza granicami kraju. Ponadto skuteczne przeprowadzenie operacji zbrojnej w Libii miało pokazać, że zdolności operacyjne Sił Zbrojnych Jej Królewskiej Mości (Her Majesty’s Armed Forces) są na wysokim poziomie. Miało to uspokoić obserwatorów i opinię publiczna, że ograniczenie wydatków na obronność nie spowoduje spadku bezpieczeństwa militarnego Wielkiej Brytanii ${ }^{18}$.

${ }^{17}$ S. Lyall, A. Cowell, Britain Plans Deepest Cuts to Spending in 60 Years, „New York Times”, 20 X 2010, http://www.nytimes.com/2010/10/21/world/europe/21britain.html (dostęp: 9 IX 2017).

${ }^{18}$ G. Gogowski, op. cit. 


\section{Przygotowania Wielkiej Brytanii do interwencji zbrojnej w Libii}

Na przełomie lutego i marca 2011 r. prezydent Francji Nicolas Sarkozy (V 2007 - V 2012) wiódł prym w przekonywaniu społeczności międzynarodowej co do konieczności przeprowadzenia interwencji zbrojnej w Libii ${ }^{19}$. W działaniu tym zdecydowanie zaczął go wspierać premier Wielkiej Brytanii David Cameron. Ci dwaj politycy na forum Organizacji Traktatu Północnoatlantyckiego (North Atlantic Treaty Organization - NATO), Unii Europejskiej (UE), ONZ i grupy wysoko rozwiniętych państw - G8 nawoływali do podjęcia zdecydowanych działań wobec Libii. Cameron szczególnie intensywnie namawiał do rozpoczęcia bezpośredniej akcji w Libii prezydenta Baracka Obamę (I 2009 - I 2017). Zabiegał on w Waszyngtonie o przeprowadzenie wspólnej operacji powietrznej w obronie mieszkańców Bengazi przed natarciem sił rządowych Kaddafiego. Gdy Brytyjczycy rozpoczęli forsowanie w Radzie Bezpieczeństwa (RB) ONZ rezolucji o ustanowieniu strefy zakazu lotów nad Libia, początkowo nie uzyskali poparcia Amerykanów. Z tego powodu premier Cameron i prezydent Obama zawiesili nawet osobiste kontakty telefoniczne. W tych okolicznościach politycy i komentatorzy w Wielkiej Brytanii sugerowali, że Londyn musi szukać innego głównego sojusznika w sprawach polityczno-wojskowych niż Waszyngton. Wskazywali wtedy na rozwijajacy się „nowy bilateralizm" między Londynem a Paryżem. Amerykańscy oficjele okazywali z kolei swoją irytację faktem, że Wielka Brytania i inni europejscy członkowie NATO postrzegaja ich jako ostatnia „deskę ratunku”, która w sytuacjach kryzysowych ma automatycznie przychodzić im z pomoca. Niezmiennie domagali się od europejskich sojuszników zwiększenia nakładów na obronność do minimalnego poziomu wymaganego w NATO $-2 \%$ PKB i wzięcia większej odpowiedzialności za własne bezpieczeństwo i stabilność sąsiednich regionów. Krytykowali samą Wielką Brytanię, która z powodu wdrażanych cięć budżetowych szybko zbliżała się do minimalnego poziomu finansowania armii ${ }^{20}$.

W kontekście kryzysu libijskiego władze brytyjskie popełniły kilka mniej lub bardziej poważnych niezręczności. Wicepremier Nick Clegg (V 2010 V 2015) w wywiadzie udzielonym podczas urlopu dał do zrozumienia, że nie ma świadomości, że pod nieobecność premiera powinien przerwać odpoczynek i sprawować w jego imieniu władzę. Minister spraw zagranicznych William Hague (V 2010 - VII 2014) stwierdził na podstawie nieprawdziwych informacji, że Muammar Kaddafi przebywa w Wenezueli. Ponadto według niego libijscy rebelianci mieli pojmać „mały zespół dyplomatyczny”, który, jak się

\footnotetext{
${ }^{19}$ House of Commons. Foreign Affairs Committee, Libya: Examination of intervention and collapse and the UK's future policy options, Third Report of Session 2016-17, London, 14 IX 2016, s. 11, https://publications.parliament.uk/pa/cm201617/cmselect/cmfaff/119/119. pdf (dostęp: 6 IX 2017).

${ }^{20}$ J. Dumbrell, op. cit., s. 99.
} 
okazało, złożony był z komandosów Powietrznej Służby Specjalnej (Special Air Service - SAS). Ujawnienie tych informacji potwierdziło doniesienia medialne, że brytyjskie jednostki specjalne działały w Libii już w lutym 2011 r., a więc przed rozpoczęciem operacji NATO ${ }^{21}$. Skutecznie przeprowadzona interwencja zbrojna miała zatrzeć te gafy i polepszyć wizerunek rządu zarówno w kraju, jak i na arenie międzynarodowej.

Premier David Cameron przedstawił trzy kryteria, które musiały zostać spełnione, aby Wielka Brytania wzięła udział w interwencji zbrojnej w Libii. Pierwszym z nich była jednoznaczna potrzeba realizacji operacji bojowej, drugim - poparcie i wsparcie ze strony państw regionu, a trzecim - jasna i niepodważalna podstawa prawna ${ }^{22}$. Za jednoznaczna potrzebą miały przemawiać działania rządowych sił bezpieczeństwa Libii wobec cywilnych demonstrantów i rebeliantów. Koronnym argumentem były masakry popełniane przez libijskie siły bezpieczeństwa, np. pacyfikacja antyrządowych demonstracji w Trypolisie 21 II 2011 r., podczas której miało zginaćc ok. 300 osób. Główny prokurator Międzynarodowego Trybunału Karnego (International Criminal Court - MTK/ ICC), Luis Moreno-Ocampo oszacował liczbę ofiar cywilnych zastrzelonych przez siły bezpieczeństwa Muammara Kaddafiego w lutym 2011 r. na 500-700. Dokładna liczna była trudna do ustalenia, ponieważ władze libijskie próbowały zacierać ślady zbrodni. Między innymi usuwano ciała ze szpitali i likwidowano ich dokumentację medyczną ${ }^{23}$. Znacznie większą liczbę ofiar pociagała za soba marcowa ofensywa libijskiej armii przeciwko zbrojnej opozycji.

Drugie kryterium zostało spełnione tylko połowicznie. Przez państwa arabskie przechodziła w tym okresie tzw. Arabska Wiosna, w trakcie której społeczeństwa Afryki Północnej i Bliskiego Wschodu występowały przeciwko satrapom od dekad sprawującym niepodzielna władzę. Protestowały one przeciwko bezrobociu, biedzie, rosnącym cenom żywności, a także korupcji, nepotyzmowi i prześladowaniom przeciwników politycznych. Masowy zryw społeczeństw arabskich miał tė̇ głębokie podłoże religijne i etniczno-plemienne ${ }^{24}$. Wśród państw arabskich znaleźli się tzw. protektorzy z ramienia ONZ w Libii - Arabia Saudyjska, Jordania, Katar i Zjednoczone Emiraty Arabskie. Były one gotowe do wsparcia NATO w działaniach zbrojnych przeciwko oddziałom Kaddafiego. Zdarzały się jednak głosy jednoznacznie przeciwne tej interwencji, w tym syryjskiego dyktatora broniącego własnej pozycji Baszszara al-Asada.

${ }^{21}$ G. Gogowski, op. cit.

22 J. Gaskarth, British Foreign Policy. Crises, Conflicts and Future Challenges, CambridgeMalden 2013, s. 87.

${ }^{23}$ M. Simons, N. MacFarquhar, Hague Court Seeks Warrants for Libyan Officials, „New York Times", 4 V 2011, http://www.nytimes.com/2011/05/05/world/africa/05nations.html (dostęp: 9 IX 2017).

${ }^{24}$ J. Armbruster, Arabska wiosna. Rewolucja w świecie islamskim, tłum. R. Kędzierski, Wrocław 2011, s. 7-8. 
Jeśli chodzi o trzecie kryterium, to premier Cameron nie chciał popełnić błędu Blaira, który wysłał brytyjskich żołnierzy na wojnę w Iraku bez autoryzacji ze strony RB ONZ. Z tego względu zdecydowanie zabiegał o rezolucję głównego gremium odpowiedzialnego za utrzymanie międzynarodowego pokoju i bezpieczeństwa. Dzięki niej mógł odeprzeć wszelkie argumenty przedstawiane $\mathrm{w}$ parlamencie i w mediach, sugerujacce bezprawności akcji zbrojnej. Doświadczenia z Iraku pokazały, że rozpoczęcie wojny bez jednoznacznych sankcji militarnych zawartych w rezolucji RB rodziło poważne spory prawne zarówno przed interwencją zbrojna, $\mathrm{w}$ jej trakcie, jak i wiele lat po jej zakończeniu. W związku z tym dla rządu brytyjskiego uchwalenie rzeczonego dokumentu było kluczowym czynnikiem w pozyskaniu krajowej i międzynarodowej opinii publicznej dla działań zbrojnych w Libii ${ }^{25}$.

26 II 2011 r. RB ONZ przyjęła rezolucję nr 1970. Zażądała od władz Libii natychmiastowego zakończenia stosowania przemocy oraz przestrzegania międzynarodowego prawa humanitarnego, praw człowieka i praw uchodźców. Zdecydowała również o zamrożeniu aktywów osób bezpośrednio związanych z libijskim reżimem. Na społeczność międzynarodową nałożyła z kolei obowiązek przestrzegania embarga na zaopatrywanie, sprzedaż i przekazywanie broni do Libii ${ }^{26}$. Wielka Brytania aktywnie zabiegała o uchwalenie w kwestii Libii kolejnej rezolucji, w której zawarte byłyby sankcje militarne. Zabiegi brytyjskiej i francuskiej dyplomacji na forum ONZ przyniosły pożądany efekt. 17 III $2011 \mathrm{r}$. RB uchwaliła rezolucję w sprawie Libii nr 1973. Zważywszy na rozkład głosów w Radzie, sukces można jednak uznać za połowiczny. Stany Zjednoczone poparły ją dopiero po pozytywnym ustosunkowaniu się Ligi Państw Arabskich (League of Arab States - LPA/LAS). Od głosu wstrzymały się natomiast państwa BRIC (Brazylia, Rosja, Indie i Chiny) oraz Niemcy. Sama treść dokumentu mogła być dla Brytyjczyków i Francuzów satysfakcjonująca. Rezolucja wezwała do natychmiastowego zawieszenia broni przez strony konfliktu i przede wszystkim zakończenia akcji zbrojnych przeciwko cywilom. Zażądała od władz Libii podjęcia wszelkich niezbędnych działań na rzecz ochrony i pomocy humanitarnej cywilom. W stosunku do społeczności międzynarodowej sankcjonowała zastosowanie wszelkich koniecznych środków w celu obrony libijskiej ludności cywilnej i obszarów zurbanizowanych. W rezolucji ustanowiono strefę zakazu lotów w przestrzeni powietrznej Libii w celu obrony cywilów, z wyłączeniem lotów z pomoca humanitarna. Państwa członkowskie ONZ zostały upoważnione do wdrożenia ustanowionej strefy zakazu lotów. W rezolucji zawarto jednak wskazanie, że żadna część

${ }^{25}$ P. Rowe, op. cit., s. 30.

${ }^{26}$ Resolution 1970 (2011). Adopted by the Security Council at its $6491^{\text {th }}$ meeting, on $26^{\text {th }}$ February 2011, Washington, 26 II 2011, http://www.un.org/en/ga/search/view_doc.asp?symbol=S/ RES/1970(2011) (dostęp: 6 IX 2017). 
terytorium Libii nie mogła być okupowana ${ }^{27}$. Stwierdzenie to interpretowano w taki sposób, że NATO nie powinno przeprowadzać w kraju operacji lądowej. U schyłku operacji zbrojnej NATO w Libii, tj. 16 IX 2011 r. RB ONZ przyjęła rezolucję nr $2009 \mathrm{w}$ sprawie przyszłości tego państwa. Zdecydowano w niej o ustanowieniu Misji Wsparcia Narodów Zjednoczonych w Libii (United Nations Support Mission in Libya - UNSMIL). Misja o charakterze politycznym miała przede wszystkim wesprzeć Libijczyków w odtworzeniu porządku, bezpieczeństwa publicznego i państwa prawa, inicjować demokratyczne procesy polityczne i społeczne oraz dynamizować odbudowę gospodarczą ${ }^{28}$.

Dysponując podstawa prawną w postaci rezolucji RB ONZ nr 1970 i 1973, w nocy z 19 na 20 III 2011 r. rozpoczęły się naloty na Libię, w których uczestniczyły statki powietrzne RAF. Należy zwrócić uwagę na fakt, że dopiero 21 marca przeprowadzono dyskusję i głosowanie w Izbie Gmin nad zaangażowaniem militarnym Wielkiej Brytanii w Libii. Tego samego dnia opublikowane zostało stanowisko prokuratora generalnego $\mathrm{w}$ tej sprawie. Przekonując parlamentarzystów do poparcia udziału brytyjskiej armii w działaniach zbrojnych w Libii, premier David Cameron obiecywał, że „nie będzie to kolejna wojna w Iraku"29. Ostatecznie politykę rządu brytyjskiego wobec Libii poparło 557 deputowanych, przy zaledwie 13 głosach przeciwnych $^{30}$. Muammar Kaddafi podtrzymał swoje oświadczenie z 22 II 2011 r., w którym ogłosił, że nigdy się nie podda i nie odda władzy w ręce „zdrajców i najeźdźców". Zapowiedział walkę do ostatniej kropli krwi swojej i swoich ludzi. Zagroził również, że każdego, kto odmówi wykonania jego rozkazu, ukarze śmiercią ${ }^{31}$.

\section{Udział brytyjskich sił zbrojnych w interwencji w Libii}

Operacja bojowa NATO w Libii miała charakter interwencji humanitarnej realizowanej w ramach koncepcji „odpowiedzialność za ochronę” (,Responsibility to Protect" - R2P). Społeczność międzynarodowa, z wykorzystaniem Sojuszu Północnoatlantyckiego, zastosowała sankcje militarne wobec władz Libii, które masowo i dotkliwie naruszały prawa człowieka wobec własnego

\footnotetext{
${ }^{27}$ Resolution 1973 (2011). Adopted by the Security Council at its $6498^{\text {th }}$ meeting, on 17 March 2011, Washington, 17 III 2011, http://www.un.org/en/ga/search/view_doc.asp?symbol=S/ RES/1973(2011) (dostęp: 6 IX 2017).

${ }^{28}$ Resolution 2009 (2011). Adopted by the Security Council at its 6620 th meeting, on 16 September 2011, Washington, 16 IX 2011, http://www.un.org/ga/search/view_doc.asp?symbol=S/ RES/2009\%20\%282011\%29 (dostęp: 6 IX 2017).

${ }_{29}$ J. Strong, Public Opinion, Legitimacy and Tony Blair's War in Iraq, London-New York 2017, s. 3.

${ }^{30}$ P. Rowe, op. cit., s. 72 .

${ }^{31}$ M. Kozłowska, op. cit.
} 
społeczeństwa ${ }^{32}$. Operacja przeprowadzona została wbrew stanowisku władz Libii, jednak naruszenie zasady suwerenności państwowej wynikało z konieczności obrony ludności przed represjami i zbrodniami. Najbardziej odpowiednim uzasadnieniem motywacji przeprowadzenia operacji zbrojnej w Libii w wymiarze aksjologicznym jest humanitaryzm ${ }^{33}$. Od strony prawnej wytłumaczenie wynika z omówionego wcześniej mandatu RB ONZ. W praktyce operacja na rzecz ochrony ludności cywilnej przekształciła się jednak w politykę zmiany reżimu w Libii metodami wojskowymi ${ }^{34}$.

Kampania lotnicza NATO w Libii pod kryptonimem „Unified Protector” (,Zjednoczony Obrońca”) przeprowadzona została między 1 III a 31 X 2011 r. Operacja składała się z trzech zasadniczych elementów: ustanowienia strefy zakazu lotów nad Libia, przestrzegania embarga na dostawy broni do tego kraju i ochrony ludności cywilnej przed atakami zbrojnymi ${ }^{35}$. Wbrew oczekiwaniom Wielkiej Brytanii Stany Zjednoczone nie interesowały się przejęciem przywódczej roli w działaniach wobec Libii. W związku z tym powinność tę wzięły na siebie Francja i Wielka Brytania, będące także stałymi członkami RB ONZ. Dla tych państw było to pierwsze praktyczne potwierdzenie podpisanego 2 XI 2010 r. brytyjsko-francuskiego traktatu w zakresie obrony. Zgodnie z porozumieniem miały one ściśle ze sobą współpracować w obszarze wojskowości i podejmować wspólne wysiłki w zakresie rozwoju zdolności $\mathrm{w}$ ramach kolektywnej obrony ${ }^{36}$. W wymiarze politycznym formalnie operacja zbrojna nadzorowana była przez przedstawicieli państw NATO w formacie poszerzonym o uczestniczące w niej państwa arabskie. Również w wymiarze militarnym kampania powietrzna w Libii zrealizowana została z wykorzystaniem struktury dowódczej NATO. Stało się tak, mimo że większość jego członków odmówiła udziału w przedsięwzięciu. Za takim rozwiązaniem zdecydowanie opowiadała się Wielka Brytania, argumentując, że Sojusz Północnoatlantycki ma doświadczenie w ustanawianiu stref zakazu lotów. Było jednak jasne, że Londynowi zależało, aby przynajmniej w kolegialny sposób zaangażować w tę operację Stany Zjednoczone. Stanowisko to różniło się od prezentowanego przez Francję, która opowiadała się za stworzeniem dowództwa francusko-brytyjskiego. Ostatecznie Stany Zjednoczone zaangażowały się

${ }^{32}$ P. Grzebyk, Ramy prawne użycia sity, w: Bezpieczeństwo międzynarodowe, red. R. Kuźniar i in., Warszawa 2012, s. 129.

${ }^{33}$ R.W. Murray, Humanitarianism, Responsibility or Rationality? Evaluating Intervention as State Strategy, w: Libya. The Responsibility to Protect and the Future of Humanitarian Intervention, red. A. Hehir, R. Murray, New York 2013, s. 15.

${ }^{34}$ House of Commons. Foreign Affairs Committee, op. cit., s. 18.

${ }_{35}$ Operation UNIFIED PROTECTOR. Final Mission Stats, 2 XI 2011, http://www.nato.int/ nato_static/assets/pdf/pdf_2011_11/20111108_111107-factsheet_up_factsfigures_en.pdf (dostęp: 6 IX 2017).

${ }^{36}$ Franco-British Defence Co-operation, London, 2 XI 2010, http://webcache.googleusercontent.com/search?q=cache:4AD_-4R3d3QJ:researchbriefings.files.parliament.uk/documents/ SN05750/SN05750.pdf+\&cd=10\&hl=pl\&ct=clnk\&gl=pl\&client=firefox-b (dostęp: 6 IX 2017). 
w misję, jednak głównie w roli sił wspierających i zabezpieczających jednostki bojowe. Polegało to przede wszystkim na obsłudze tankowania w powietrzu, dostarczaniu pocisków precyzyjnego rażenia i obsłudze systemów ich naprowadzania ${ }^{37}$. Ponadto miały istotny wpływ na strategię operacji w Libii, dlatego też ich udział $\mathrm{w}$ tym przedsięwzięciu, jak i szerzej $\mathrm{w}$ działaniach Zachodu wobec Arabskiej Wiosny, często określany był jako „kierowanie z tylnego siedzenia”. Spośród państw członkowskich Sojuszu Północnoatlantyckiego w operacji militarnej w Libii, poza siłami zbrojnymi Francji, Wielkiej Brytanii i Stanów Zjednoczonych, uczestniczyły również jednostki z Belgii, Bułgarii, Danii, Grecji, Hiszpanii, Holandii, Kanady, Norwegii, Rumunii, Turcji i Włoch. Spoza NATO brały w niej udział Jordania, Katar, Szwecja i Zjednoczone Emiraty Arabskie.

W szczytowym momencie operacji „Unified Protector” państwa kontrybutorzy zaangażowały ok. 8 tys. żołnierzy, ponad 260 statków powietrznych różnego typu i 21 okrętów różnego typu ${ }^{38}$. Podczas całej operacji liczba wykorzystanych żołnierzy i sprzętu wojskowego była nieporównywalnie wyższa i obejmowała m.in. 60 okrętów różnego typu. Znaczący w tym udział miały Siły Zbrojne Jej Królewskiej Mości. Królewska Marynarka Wojenna (Royal Navy) rozmieściła na akwenach w pobliżu wybrzeży Libii szereg okrętów Jej Królewskiej Mości (Her Majesty's Ship - HMS), tj. 3 fregaty typu 23 - HMS „Westminster”, HMS „Sutherland” i HMS „Iron Duke”, fregatę typu 22 - HMS „Cumberland”, niszczyciela typu 42 - HMS „Liverpool”, nuklearne łodzie podwodne klasy Trafalgar - HMS „Triumph” i HMS „Turbulent”, poławiacz min klasy Hunt - HMS „Brocklesby”, trałowiec klasy Sandown - HMS „Bangor”, amfibię transportowa klasy Albion - HMS „Albion”, amfibię szturmowa HMS „Ocean”. Z Królewskich Sił Pomocniczych (Royal Fleet Auxiliary - RFA) zaangażowano tankowiec klasy Wave - RFA „Wave Knight” i okręt zaopatrzenia RFA „Fort Rosalie”. Okręty te realizowały głównie zadania z zakresu patrolowania i obserwacji, ale także, zgodnie z przeznaczeniem, m.in. ostrzału rakietowego i lądowiska dla śmigłowców. Królewskie Siły Powietrzne wykorzystywały do misji bojowych 16 myśliwców wielozadaniowych Panavia „Tornado” i 10 myśliwców wielozadaniowych Eurofighter „Typhoon”. Do obserwacji powietrznej używano samolotów wywiadu sygnałowego Hawker Siddeley „Nimrod” R1 i Raytheon „Sentinel” R1 oraz 3 samoloty Lotniczego Systemu Ostrzegania i Kontroli (Airborne Warning and Control System - AWACS) Boeing E-3 „Sentry”. Towarzyszyło im wiele wspomagających statków powietrznych, w tym samolot tankowania powietrznego Vickers VC10, 4 śmigłowce szturmowe AgustaWestland „Apache” AH1 i 2 śmigłowce wielozadaniowe AgustaWestland „Lynx”. Brytyjskie samoloty korzystały zarówno z baz w Wielkiej Brytanii, brytyjskiej bazy Akrotiri na

${ }^{37}$ D. Gowland, Britain and the European Union, London-New York 2017, s. 298.

38 Operation UNIFIED PROTECTOR... 
południowym Cyprze, jak i włoskiej bazy Gioia del Colle na południu Półwyspu Apenińskiego. W naprowadzaniu powietrznego i morskiego ostrzału pomagali rozmieszczeni w Libii komandosi Powietrznej Służby Specjalnej, Nawodnej Służby Specjalnej (Special Boat Service - SBS) i Specjalnego Pułku Rozpoznania (Special Reconnaissance Regiment - SRR) ${ }^{39}$.

Wkład Sił Zbrojnych Jej Królewskiej Mości w operację wojskową w Libii w 2011 r. mógłby być bardziej znaczący i skuteczny, gdyby skierowały one w rejon kryzysu lotniskowiec, tak jak uczyniły to Stany Zjednoczone i Francja $^{40}$. Nie stało się tak ze względu na ograniczone możliwości Królewskiej Marynarki Wojennej w tym zakresie. W ostatnich latach wycofane zostały ze służby wszystkie 3 lekkie lotniskowce klasy Invincible - w 2005 r. HMS „Invincible”, w 2011 r. HMS „Ark Royal” i w 2016 r. HMS „Illustrious”. Dopiero w najbliższych latach brytyjska flota ma zostać zasilona 2 dużymi lotniskowcami uderzeniowymi klasy Queen Elizabeth - w 2020 r. HMS „Queen Elizabeth” i w 2021 r. HMS „Prince of Wales”. Oznacza to, że przynajmniej w okresie przejściowym zdolności Wielkiej Brytanii w zakresie lotniskowców są i nadal będą ograniczone. Przekłada się to przede wszystkim na ograniczona możliwość prowadzenia przez Brytyjczyków działań zbrojnych na pozaeuropejskich teatrach konfliktów i kryzysów militarnych.

Podczas operacji „Unified Protector” istotna część nalotów realizowana była na terenach zurbanizowanych, czasem o wysokim zagęszczeniu ludności. Zważywszy na specyfikę misji bojowej, Brytyjczycy, podobnie jak Francuzi, podczas wielu lotów uderzeniowych musieli używać precyzyjnie naprowadzanych pocisków. Było to konieczne do uniknięcia lub minimalizacji ofiar cywilnych i zniszczeń ich majątku, jednak wiązało się z wysokimi kosztami. W tym celu przede wszystkim korzystano z amerykańskich taktycznych pocisków manewrujacych „Tomahawk”. Przy okoliczności nalotów na Libię rząd brytyjski ogłosił, że jednym z jego priorytetów będzie inwestowanie $\mathrm{w}$ badania nad technologiami nowoczesnej amunicji i jej nabywanie. Zgodnie z założeniami stopniowo ma ona wypierać pociski mniejszej precyzji, które stanowią większość obecnych zapasów ${ }^{41}$.

W ramach operacji powietrznej NATO w Libii przeprowadzono ponad 26,5 tys. lotów, z czego ponad 9,7 tys. lotów uderzeniowych. Zniszczono ponad 5,9 tys. celów wojskowych, w tym ponad 400 jednostek artylerii i wyrzutni rakiet oraz ponad 600 czołgów i wozów opancerzonych ${ }^{42}$. RAF

39 Typhoon joins Tornado in Libya ground attack operations, 13 IV 2011, https://www.gov. uk/government/news/typhoon-joins-tornado-in-libya-ground-attack-operations (dostęp: 6 IX 2017); P. Wintour, Libya: UK to increase number of Tornado jets, „The Guardian”, 4 IV 2011, https://www.theguardian.com/world/2011/apr/04/libya-uk-increase-tornado-jets (dostęp: 9 IX 2017).

${ }^{40}$ S. Marsh, The Anglo-American defence relationship, w: Anglo-American Relations..., s. 197.

${ }^{41}$ P. Rowe, op. cit., s. 214.

${ }^{42}$ Operation UNIFIED PROTECTOR... 
zrealizował jedna piątą całkowitej liczby wykonanych nad Libią lotów uderzeniowych $^{43}$. Na brytyjskie statki powietrzne przypadło jednak aż $25 \%$ godzin lotu ${ }^{44}$. W ramach embarga na dostawy broni do Libii wywołano do odpowiedzi ponad 3,1 tys. statków i wkroczono na pokład ok. $300 \mathrm{z}$ nich ${ }^{45}$. W działania te istotnie zaangażowana była Królewska Marynarka Wojenna. Według danych Ministerstwa Obrony Wielkiej Brytanii koszt udziału Brytyjczyków w operacji „Unified Protector” wyniósł 212 mln funtów ${ }^{46}$. W prasie brytyjskiej pojawiły się jednak liczne szacunki wskazujace znacznie wyższe kwoty, sięgające nawet 1,25 mld funtów ${ }^{47}$. Jeśli bliższe rzeczywistości są górne szacunki, mogłoby to oznaczać, że Wielka Brytania poniosła najwyższy koszt finansowy uczestnictwa w operacji wojskowej w Libii spośród wszystkich zaangażowanych w nią państw.

Jak wcześniej wspomniano, Sojusz Północnoatlantycki przykładał szczególną wagę, aby podczas bombardowań możliwie zminimalizować liczbę ofiar po stronie cywilów. Według organizacji Human Rights Watch starania te przyniosły pozytywny efekt. Liczba ofiar cywilnych w Libii w wyniku nalotów NATO była niska w stosunku do zakresu i intensywności bombardowań oraz długości kampanii wojennej. W bezpośredniej konsekwencji nalotów sił NATO udokumentowano śmierć 72 cywilów, spośród których jedną trzecia stanowiły osoby poniżej 18. roku życia. Sojusz nie uznał jednak tych danych, jak również nie przeprowadził śledztw, które mogłyby wyjaśnić przyczyny śmierci wskazanych cywilów ${ }^{48}$. Całościowo w walkach do zakończenia operacji bojowej NATO w Libii według szacunków Rady Praw Człowieka ONZ (United Nations Human Rights Council - UNHRC) zginęło od 10 do 15 tys. osób ${ }^{49}$. Warto wspomnieć, że państwa członkowskie NATO zaangażowały się w pomoc humanitarną i medyczną dla ofiar konfliktu libijskiego, w tym samej operacji „Unified Protector”. Między innymi rząd brytyjski sfinansował i zorganizował za pośrednictwem Międzynarodowego Komitetu Czerwonego Krzyża (International Committee of the Red Cross - ICRC) grupy, które udzielały pomocy medycznej i dostarczały zapasy medyczne dla 3 tys. ludzi

${ }^{43}$ P. Rowe, op. cit., s. 43.

${ }^{44}$ Typhoon joins...

${ }^{45}$ Operation UNIFIED PROTECTOR...

${ }^{46}$ Cost of Libya operations, 8 XII 2011, https://www.gov.uk/government/news/cost-of-libyaoperations (dostęp: 6 IX 2017).

${ }^{47}$ N. Hopkins, UK operations in Libya: the full costs broken down, „The Guardian”, 26 IX 2011, https://www.theguardian.com/news/datablog/2011/sep/26/uk-operations-libya-costs (dostęp: 9 IX 2017).

48 Unacknowledged Deaths. Civilian Casualties in NATO’s Air Campaign in Libya, $13 \mathrm{~V}$ 2012, https://www.hrw.org/report/2012/05/13/unacknowledged-deaths/civilian-casualties-natos-air-campaign-libya (dostęp: 9 IX 2017).

${ }^{49}$ Reuters Staff, Up to 15,000 killed in Libya war: U.N. rights expert, 9 VI 2011, https://www. reuters.com/article/us-libya-un-deaths/up-to-15000-killed-in-libya-war-u-n-rights-expertidUSTRE7584UY20110609 (dostęp: 9 IX 2017). 
dotkniętych trwającymi walkami. Włączenie w te działania niezależnej i bezstronnej międzynarodowej organizacji humanitarnej miało na celu dodatkowe legitymizowanie polityki Brytyjczyków wobec Libii ${ }^{50}$. Po stronie państw NATO w trakcie operacji w Libii śmierć poniósł tylko jeden żołnierz, który pochodził z Wielkiej Brytanii ${ }^{51}$. Zgon nie miał jednak bezpośredniego związku $\mathrm{z}$ działaniami zbrojnymi, a nawet nie nastapił w samej Libii. Starszy szeregowy lotnictwa James Smart z 2 szwadronu transportu mechanicznego RAF zginą 20 VII 2011 r. w południowych Włoszech w wyniku ran odniesionych w wypadku samochodowym ${ }^{52}$.

\section{Konsekwencje interwencji zbrojnej w Libii i zaangażowania w niej Wielkiej Brytanii}

Członkowie międzynarodowej koalicji wojskowej skupili się na militarnych sposobach reagowania na kryzys w Libii, rezygnując tym samym z poszukiwania politycznych dróg jego rozwiązania. Po zapewnieniu bezpieczeństwa mieszkańcom Bengazi rząd Davida Camerona nie zdecydował się na wdrożenie politycznych mechanizmów współpracy z rządem Muammara Kaddafiego na rzecz kompleksowej ochrony ludności, demokratyzacji systemu politycznego i reform społeczno-gospodarczych. Nie był również zainteresowany skorzystaniem w tym zakresie z kontaktów i wpływów wśród oficjeli libijskiego reżimu, jakie przez lata wypracowali członkowie gabinetu i administracji premiera Tony’ego Blaira ${ }^{53}$. Trudno było jednak oczekiwać, że libijski dyktator zgodziłby się na poważniejsze ustępstwa. Równie mało prawdopodobne, że ugrupowania rebelianckie zaakceptowałyby utrzymanie się u władzy Kaddafiego. Silna władza jest w Libii bardzo potrzebna, jednak nie może być ona obarczona zbrodniami na tysiącach własnych obywateli.

Dzięki przeprowadzeniu przez NATO operacji bojowej „Unified Protector” udało się obalić reżim Muammara Kaddafiego i przekazać władzę w ręce opozycyjnej Przejściowej Rady Narodowej Libii. Brytyjczycy wierzyli, że po obaleniu zbrodniczego reżimu Libia wkroczy na drogę demokratyzacji, stabilizacji i rozwoju. Nowe władze nie były jednak w stanie efektywnie przejać funkcji rządowych, szczególnie w obszarze bezpieczeństwa i porządku publicznego. W związku z tym sytuacja w kraju zaczęła ulegać destabilizacji.

${ }^{50}$ P. Rowe, op. cit., s. 140.

${ }^{51}$ UK Armed Forces Operational deaths post World War II, 4 XI 2014, s. 4, https://www.gov. uk/government/uploads/system/uploads/attachment_data/file/369400/20141104_UK_Armed_ Forces_Operational_deaths_post_World_War_II_O.pdf (dostęp: 6 IX 2017).

52 Senior Aircraftman James Smart killed in Italy road accident, 22 VII 2011, https://www. gov.uk/government/news/senior-aircraftman-james-smart-killed-in-italy-road-accident (dostęp: 6 IX 2017).

${ }^{53}$ House of Commons. Foreign Affairs Committee, op. cit., s. 20. 
Jednym z głównych czynników pogorszenia się stanu bezpieczeństwa w Libii była nieumiejętność sprawnego odtworzenia państwowych sił bezpieczeństwa. Nowe władze opłacały tysiące bojowników, których lojalność miała zazwyczaj charakter lokalny, a nie narodowy. Znaczna część uzbrojonych i wspartych nalotami NATO libijskich rebeliantów, w tym islamistów, odrzuciła wezwanie do złożenia broni i zaakceptowania sił bezpieczeństwa formowanych przez tymczasowe władze Libii.

Zbrojna rywalizacja o terytorium między poszczególnymi ugrupowaniami polityczno-militarnymi natychmiast doprowadziła do wybuchu kolejnej wojny domowej. Jej eskalacja nastapiła jednak w 2014 r. po przeprowadzeniu wyborów parlamentarnych. W ich wyniku nastapił rozłam w strukturach państwowych i od tego momentu główna oś konfliktu istniała między wyłonioną demokratycznie Izbą Reprezentantów (House of Representatives - HoR) a stworzonym przez przegrany blok ugrupowań politycznych Powszechnym Kongresem Narodowym (General National Congress - GNC). HoR dysponująca zbrojnym ramieniem w postaci podległej mu Libijskiej Armii Państwowej (Libyan National Army - LNA) kontroluje wschodnia Libię. Korzysta ona również z wydatnego wsparcia, także militarnego, z zewnątrz, tj. ze strony Egiptu, Zjednoczonych Emiratów Arabskich, Jordanii i Arabii Saudyjskiej. GNC obecnie nie istnieje, ponieważ w kwietniu $2016 \mathrm{r}$. formalnie został rozwiązany. Wcześniej kontrolował on znaczne tereny zachodniej Libii, a jego militarnym skrzydłem była koalicja różnych ugrupowań zbrojnych, zwana „Libya Dawn Coalition”. W jej ramach istotną rolę odgrywały zamieszkujące zachodnia Libię i sasiednie państwa regionu ludy Berberów i Tuaregów. Zewnętrzne wsparcie otrzymywał on głównie od Kataru, Sudanu i Turcji. Mimo że GNC został rozwiązany, niektóre ugrupowania wchodzące wcześniej w jego skład nadal prowadzą działania zbrojne. W grudniu $2015 \mathrm{r}$. w wyniku negocjacji między HoR i GNC utworzono Rząd Zgody Narodowej (Government of National Accord - GNA). Mimo że rząd ten do dziśs funkcjonuje, to jego zwierzchnictwo nad Libia nie jest jednoznaczne. Wynika to z szeregu konfliktów kompetencyjnych między jego członkami i rywalizacji o wpływy nad poszczególnymi terytoriami wchodzących w jego skład ugrupowań. W wojnie domowej w Libii uczestniczyło i nadal uczestniczy również szereg mniejszych ugrupowań. Są to m.in. wspierana przez GNC islamistyczna Rada Szury Rewolucjonistów Bengazi (Shura Council of Benghazi Revolutionaries), dżihadystyczne Państwo Islamskie Iraku i Lewantu w Libii (Islamic State of Iraq and the Levant in Libya - ISIL in Libya), milicje Tuaregów z Ghat (Tuareg militias of Ghat) oraz wiele innych ugrupowań, głównie o charakterze lokalnym. Libia nadal podzielona jest na strefy wpływów, jednak dominująca pozycję mają obecnie HoR i GNA.

Po przeprowadzonej w 2011 r. operacji zbrojnej społeczność międzynarodowa, w której dominujaca rolę odgrywały Francja i Wielka Brytania, nie była w stanie opracować i wdrożyć skutecznej strategii wobec Libii. Nie 
potrafiono nawet zabezpieczyć arsenałów broni pozostawionych po obalonej władzy, które przejęte zostały przez poszczególne ugrupowania rebelianckie, a w pewnym stopniu również organizacje terrorystyczne. W państwie rozwinęły się anarchia i bezprawie, co stworzyło dogodne warunki działania dla terrorystów i przestępców, w tym przemytników broni i ludzi. Skala tej aktywności wykroczyła daleko poza samą Libię. Międzynarodowa siatka terrorystyczna, z przewodnią rolą ISIL, umacniała swoja pozycję w całym regionie. Konflikt w Libii stał się paliwem dla aktywności grup islamistycznych i terrorystycznych w przynajmniej 10 państwach Afryki Północnej i Środkowej. Przykładowo członkowie grupy etnicznej Tuaregów, służący wcześniej w armii Kaddafiego, przedostali się do północnego Mali z ogromnymi zapasami broni, którą wykorzystali do wszczęcia powstania separatystycznego. Tak zwany efekt spill-over (,rozlewania się”) doprowadził do rozprzestrzeniania się niestabilności z Libii w regionie. Upadek państwa libijskiego przede wszystkim przyczynił się do powstania lub wzmocnienia nielegalnych grup zbrojnych w Mali, Tunezji, Algierii, Nigrze, Czadzie, Sudanie i Egipcie. Ważnym czynnikiem wzrostu aktywności rebelianckiej i terrorystycznej była libijska broń, która trafiła do ponad 20 państw regionu ${ }^{54}$. Także libijscy przemytnicy ludzi działają w skali międzynarodowej, organizując nielegalny przerzut uchodźców i emigrantów z niestabilnych i biednych państw Afryki i Azji do Europy. Czynią to w sposób uragajacy najbardziej podstawowym zasadom humanitaryzmu, skazując $\mathrm{w}$ ten sposób tysiące z nich na śmierć, głównie w wyniku utonięcia w wodach Morza Śródziemnego. Mimo ogromnego ryzyka popyt na ich przestępcze usługi nie słabnie, szczególnie wśród obywateli państw pogrążonych wojną, jak Syria czy Afganistan. Także w samej Libii znajduja oni liczne grupy gotowych na wszystko uciekinierów. Władze w Libii wprawdzie nie sa w stanie podać wiarygodnych danych dotyczących ofiar śmiertelnych wojny domowej, jednak najprawdopodobniej jest to kilkanaście tysięcy osób ${ }^{55}$. Ponadto 425 tys. Libijczyków opuściło swoje domostwa i przeniosło się w inny rejon kraju, a ok. miliona $z$ niego uciekło ${ }^{56}$.

Walka zbrojna między poszczególnymi stronnictwami i konieczność pośpiesznego sformowania sił bezpieczeństwa wydatnie podkopały ograniczone zdolności instytucjonalne i finansowe państwa libijskiego. Nowe władze nie były w stanie $\mathrm{w}$ odpowiedni sposób wchłonąć i zagospodarować

${ }^{54}$ L. Dearden, How David Cameron's intervention in Libya is fuelling war and terror around the world, „The Independent”, 15 IX 2016, http://www.independent.co.uk/news/world/africa/ libya-report-britain-uk-gaddafi-civil-war-david-cameron-responsible-terrorism-isis-al-qaedamali-a7309821.html (dostęp: 9 IX 2017).

55 S. Raghavan, A day in Libya's capital, just as the civil war reignites, „Washington Post”, 26 V 2017, https://www.washingtonpost.com/world/heavy-fighting-between-rival-militiaserupts-in-the-libyan-capital/2017/05/26/ab7ebba4-907f-4d4e-a176-b2a442afe285_story.html (dostęp: 9 IX 2017).

${ }^{56}$ L. Dearden, op. cit. 
ograniczonego wsparcia finansowego i zasobów dostarczanych przez społeczność międzynarodową. Sama Wielka Brytania nieprzychylnie odnosiła się do udzielania Libii poważniejszego wsparcia w zakresie utrzymania bezpieczeństwa i rekonstrukcji państwa. Przede wszystkim było to konsekwencją złych doświadczeń z procesu stabilizacji powojennego Iraku ${ }^{57}$. Niemniej jednak po interwencji zbrojnej brytyjscy komandosi z SAS nadal działali w Libii, przede wszystkim zwalczając tamtejsze organizacje terrorystyczne, głównie ISIL $^{58}$.

Dokumenty odnalezione w Libii po obaleniu reżimu Kaddafiego pokazały, że władze i wywiady Wielkiej Brytanii i Libii współpracowały ze sobą w wielu kontrowersyjnych kwestiach, które przez lata ukrywane były przed opinia publiczna. Przykładowo tajny dokument Centralnej Agencji Wywiadowczej USA (Central Intelligence Agency - CIA) znaleziony w opuszczonym budynku w Trypolisie ujawnił, że Brytyjczycy współdziałali z Libijczykami w celu zaaranżowania przeniesienia podejrzanego o działalność terrorystyczną Abu Munthira wraz z żoną i dziećmi z Hongkongu do Trypolisu. Miało się to odbyć mimo dużego prawdopodobieństwa, że mogli oni być torturowani w Libii. Oskarżony miał zachęcać grupę brytyjskich muzułmanów do przeprowadzenia ataku bombowego w południowo-wschodniej części Anglii ${ }^{59}$. Inny odnaleziony dokument sugerował, że wywiad brytyjski - MI6 znacznie bliżej współpracował z agencjami wywiadowczymi Kaddafiego, niż podawano to do publicznej wiadomości, oraz że był zaangażowany w liczne operacje prowadzone przez USA przekazywania islamistów do libijskich więzień ${ }^{60}$.

Sytuacja w Libii istotnie wpływała na relacje Wielkiej Brytanii z Francja i Stanami Zjednoczonymi. Jak już wspomniano, w trakcie przygotowywania się do interwencji zbrojnej w Libii stosunki między Londynem i Paryżem były zacieśniane, podczas gdy na linii Londyn-Waszyngton pojawiło się ich tymczasowe rozluźnienie. Późniejsze militarne zaangażowanie wszystkich trzech państw w Libii prowadziło ku bliskiej trójstronnej współpracy wojskowej i zacieśnieniu stosunków politycznych ${ }^{61}$. Szczególnie bliska była współpraca między Londynem i Paryżem, czemu dało wyraz wspólne świętowanie w Bengazi premiera Davida Camerona i prezydenta Nicolasa Sarkozy'ego po obaleniu Muammara Kaddafiego. W bliskim czasie sytuacja w Libii przestała

${ }^{57}$ House of Commons. Foreign Affairs Committee, op. cit., s. 24, 27-29.

${ }^{58}$ R. Donaghy, Britain is at war in Libya and nobody thought to tell us, „The Independent”, $28 \mathrm{~V}$ 2016, http://www.independent.co.uk/voices/britain-is-at-war-in-libya-and-nobodythought-to-tell-us-a7052356.html (dostęp: 9 IX 2017).

${ }^{59}$ Full text of a CIA document indicating UK role in rendition of a terror suspect, „The Guardian”, 4 IX 2011, https://www.theguardian.com/world/2011/sep/04/secret-cia-rendition-document (dostęp: 6 IX 2017).

${ }^{60}$ I. Cobain, M. Chulov, Libyan papers show UK worked with Gaddafi in rendition operation, „The Guardian”, 4 IX 2011, https://www.theguardian.com/world/2011/sep/04/libyan-papersshow-uk-rendition (dostęp: 9 IX 2017).

${ }^{61}$ S. Marsh, op. cit., s. 192. 
być jednak powodem do wspólnego celebrowania sukcesu przez przywódców tych państw. Bardziej istotnemu pogorszeniu uległy jednak stosunki między rządem Davida Camerona i administracją Baracka Obamy. Stało się tak, gdy amerykański prezydent w publicznych wystapieniach zaczą informować o niepożądanych następstwach „francusko-brytyjskiej” operacji zbrojnej w Libii. Przy okazji tych przemówień sugerował, że anglo-amerykańskie „specjalne relacje" będą zagrożone, jeśli Wielka Brytania nie zobowiąże się do przeznaczania na obronność przynajmniej wymaganego w NATO minimum $2 \% \mathrm{PKB}^{62}$.

\section{Podsumowanie i perspektywy dalszego zaangażowania Wielkiej Brytanii w Libii}

Czynny udział w rozwiązywaniu konfliktów międzynarodowych, w tym $\mathrm{w}$ operacji humanitarnej w Libii, pokazuje, że polityki bezpieczeństwa Wielkiej Brytanii nie formułuje się stricte $\mathrm{w}$ duchu podejścia realistycznego. Sa to bowiem postawy charakterystyczne dla liberalnego internacjonalizmu. Warto także zwrócić uwagę na fakt istnienia luki w komunikowaniu się władz brytyjskich ze społeczeństwem w tym zakresie. Polega ona na różnicy pomiędzy tym, co musi być zakomunikowane a tym, co nie może być jawnie odkryte przed społeczeństwem. Do pierwszej kategorii należy przeświadczenie, że interwencje zbrojne poza granicami kraju, podejmowane w imię kolektywnej obrony, de facto realizowane sa w interesie narodowym Wielkiej Brytanii. Do drugiej kategorii zalicza się przekonanie władz, że jeśli nawet nie sa one bezpośrednio przeprowadzane $\mathrm{w}$ interesie narodowym, czasem i tak należy się w nie zaangażować. Mimo że władze brytyjskie ukrywaja przed społeczeństwem sytuacje drugiego rodzaju, to czasem dla brytyjskiej opinii publicznej i tak jest jasne, że działania zbrojne poza granicami państwa nie wynikają z obrony jej interesów. W takiej sytuacji władze musza posiłkować się argumentem, że interesy bezpieczeństwa Wielkiej Brytanii nie sa odseparowane od szerszych, kolektywnych interesów bezpieczeństwa ${ }^{63}$. Taka konieczność pojawiła się w kontekście zaangażowania się Wielkiej Brytanii w interwencję zbrojna w Libii. Wynikało to z faktu, że rząd Davida Camerona nie mógł wskazać jednoznacznego, namacalnego związku między sytuacja $\mathrm{w}$ tym państwie a bezpieczeństwem Brytyjczyków. Z tego względu przeważała argumentacja polegająca na ogólnoludzkim humanitaryzmie. Wskazywanie przez rząd Davida Camerona potencjalnego związku między kryzysem w Libii a bezpieczeństwem Wielkiej Brytanii miało jedynie charakter wtórny, uzupełniający.

\footnotetext{
${ }^{62}$ D. Gowland, op. cit., s. 286.

${ }^{63}$ T.W. Cawkwell, UK Communication Strategies for Afghanistan, 2001-2014, London-New York 2016, s. 157.
} 
W kontekście interwencji zbrojnej w Libii pojawiały się opinie, że może ona stać się precedensem dla kolejnych operacji humanitarnych. Otwarte pozostaje pytanie, czy w podejściu do Libii państwa realizujące tę misję, w tym Wielka Brytania, zmieniły swoje strategiczne preferencje i działały jako „stróże moralności”. Oznaczałoby to wkroczenie w nową erę bezinteresownej pomocniczości, w której pozostawiono za sobą egoistyczne motywacje państwowe. Ponadto byłoby to przewartościowanie polityki międzynarodowej państw od racjonalnej w kierunku odpowiedzialnej ${ }^{64}$. Już wcześniejszy premier Tony Blair w przemówieniu w Chicago z kwietnia 1999 r. zadeklarował w kontekście wojny w Kosowie, że będzie to sprawiedliwa wojna o wartości. Próbował wtedy stworzyć nową doktrynę dla społeczności międzynarodowej, opartą na wspólnej obronie moralnych celów i przekonann ${ }^{65}$. Podczas przemówienia wskazał dwóch ówczesnych tyranów, których należało obalić - Slobodana Miloševicia i Saddama Husajna ${ }^{66}$. Podobna retorykę stosował po zamachach terrorystycznych na World Trade Center. Stwierdził wtedy, że międzynarodowa siatka terrorystyczna zagraża wartościom takim jak wolność, demokracja i rządy prawa, dlatego konieczna jest wspólna walka w ich obronie ${ }^{67}$. Był to sygnał, że Wielka Brytania chce odegrać ważną rolę w koalicji zwalczającej zbrodnicze dyktatury i despotyczne rządy oraz wszystkich innych, którzy zagrażają bezpieczeństwu własnych obywateli i społeczności międzynarodowej. Niemniej jednak nie można zapominać, że włączając się w tego rodzaju działania zbrojne, Wielka Brytania i inne mocarstwa realizują również szereg partykularnych interesów różnego typu, w tym głównie politycznych, gospodarczych i w zakresie bezpieczeństwa.

W 2011 r. władze brytyjskie nie miały wystarczajaco dużo odwagi, aby stać się faktycznym przywódca międzynarodowej koalicji prowadzącej działania zbrojne w Libii. W odróżnieniu od Francji Wielka Brytania różnymi sposobami starała się włączyć do współpracy globalne supermocarstwo - Stany Zjednoczone. Gdy okazało się, że nie sa one zainteresowane przewodzeniem tej misji, Brytyjczycy zabiegali o jej realizację w ramach Sojuszu Północnoatlantyckiego. Pokazało to, że Wielka Brytania nie jest gotowa do prowadzenia w pełni samodzielnej polityki zagranicznej. Podobnie jak w okresie zimnej wojny i wojny z globalnym terroryzmem, nadal priorytet stanowiło dla niej zabieganie o utrzymanie „specjalnych relacji” ze Stanami Zjednoczonymi w zakresie bezpieczeństwa międzynarodowego. W okolicznościach

\footnotetext{
${ }^{64}$ R.W. Murray, op. cit., s. 15-16.

${ }^{65}$ C. Hodge, Britain and the Balkans. 1991 until the Present, London-New York 2006, s. 152.

66 J.M. Sharp, Tony Blain nurtures the special relationship, w: Why did the United States Invade Iraq?, red. J.K. Cramer, A.T. Thrall, London-New York 2012, s. 176.

${ }^{67}$ V.M. Kitchen, The Globalization of NATO. Intervention, Security and Identity, LondonNew York 2010, s. 97.
} 
kryzysu libijskiego nie można jednak dziwić się Londynowi, że forsował postawę proatlantycką. Wynika to $\mathrm{z}$ faktu, że w ramach UE istniały sprzeczne stanowiska w kwestii podejścia do wojny domowej w tym kraju. Po raz kolejny odkryta została w ten sposób słabość Wspólnej Polityki Zagranicznej i Bezpieczeństwa (Common Foreign and Security Policy - WPZiB/CFSP) Unii. W samej operacji wzięło udział zaledwie 11 członków UE. Pokazało to, że Europa nie była zdolna do wypracowania spójnej polityki wobec kryzysu, który pojawił się w jej bezpośrednim sasiedztwie. Zarazem oznaczało to porażkę dyplomacji brytyjskiej i francuskiej, które nie mogły stworzyć w ramach Unii jednolitej koalicji. Sama realizacja operacji „Unified Protector” pokazała, że zdolności militarne zjednoczonej Europy, w tym Wielkiej Brytanii, sa bardzo ograniczone. Ukazana po raz kolejny impotencja polityczna i militarna państw UE mogła w pewnym stopniu przyczynić się do późniejszej decyzji Brytyjczyków o opuszczeniu struktur tej organizacji. Kryzys libijski pokazał jednak, że Stany Zjednoczone, na które stawiają Brytyjczycy, w przyszłości moga mniej angażować się w bezpieczeństwo Europy lub jej bezpośredniego sasiedztwa ${ }^{68}$.

14 IX 2016 r. Brytyjska Komisja Spraw Zagranicznych Wielkiej Brytanii (Foreign Affairs Committee) wydała raport dotyczący zaangażowania się Wielkiej Brytanii w konflikt zbrojny w Libii. Główną tezą raportu było stwierdzenie, że rząd Davida Camerona popełnił wiele błędów w podejściu do tego kryzysu. Według Komisji z powodu niekompletnego wywiadu i niewystarczającej wnikliwości instytucjonalnej nie był on w stanie poprawnie zdiagnozować natury rebelii w tym kraju. Zgodnie z raportem strategia rządu brytyjskiego wobec Libii bazowała na błędnych założeniach i niepełnym zrozumieniu dowodów. Przede wszystkim nie ocenił on poprawnie poziomu zagrożenia dla ludności cywilnej Libii, wyolbrzymiając jego skalę. Wynikało to m.in. z przykładania zbytniej wagi do konfrontacyjnej retoryki Muammara Kaddafiego. Nie dostrzegł również, że w skład oddziałów rebelianckich wchodziły znaczace zgrupowania islamistyczne ${ }^{69}$. Rzą Davida Camerona odrzucił krytykę wynikającą z raportu. Utrzymywał on, że interwencja zbrojna w Libii ocaliła wiele istnień ludzkich, a działajace w kraju ISIL zostało osłabione ${ }^{70}$. Raport wydaje się dość jednostronny i przede wszystkim pisany z perspektywy czasowej, w której znane są negatywne następstwa interwencji zbrojnej w Libii. Decyzja o interwenci zbrojnej w Libii nie może być jednoznacznie krytykowana. Wynika to z faktu, że reżim Kaddafiego popełnił szereg zbrodni

68 S. Biscop, The UK and European defence: leading or leaving?, „International Affairs” 2012, t. LXXXVIII, nr 6, s. 1309.

${ }^{69}$ House of Commons. Foreign Affairs Committee, op. cit., s. 15.

${ }^{70}$ Agence France-Presse, British government insists intervention in Libya 'undoubtedly' saved lives, „The Guardian”, 25 XI 2016, https://www.theguardian.com/world/2016/nov/25/ british-government-intervention-libya-saved-lives (dostęp: 9 IX 2017). 
na własnym narodzie i społeczeństwach innych państw. Dyskusyjna może być jedynie ich skala. Jednocześnie skupienie się przez Brytyjczyków i inne państwa koalicji na działaniach stricte militarnych, traktując za drugorzędne, a nawet trzeciorzędne przedsięwzięcia o charakterze politycznym, społecznym i gospodarczym, z pewnością było błędem. Bez wątpienia na krytykę zasługuje również nieumiejętność zbierania i analizowania informacji dotyczących poszczególnych ugrupowań działających na libijskiej scenie polityczno-militarnej.

Obecnie Wielka Brytania powinna skupić się na działaniach na rzecz przeciwdziałania rozwojowi zjawiska terroryzmu na terytorium Libii, w tym zwalczania ISIL. W tym celu ważne jest szkolenie libijskich sił bezpieczeństwa. Wielka Brytania mogłaby się jednak zaangażować w ten proces jedynie na prośbę libijskiego GNA i przy jednoznacznej autoryzacji ze strony RB ONZ. Taka misja szkoleniowa powinna być realizowana przez koalicję, w która wchodziliby żołnierze zarówno państw NATO, jak i przede wszystkim państw regionu. Najlepiej gdyby została ona przeprowadzona przez LPA przy wsparciu Unii Afrykańskiej (African Union - UA/AU), UE i NATO. Na takie rozwiazanie trudno jednak liczyć z powodu słabości i rozczłonkowania pierwszych dwóch organizacji. Kolejnym priorytetem dla Wielkiej Brytanii powinny być wieloaspektowe przedsięwzięcia na rzecz wzmocnienia struktur państwowych Libii. Pomocy instytucjonalno-prawnej winny towarzyszyć zachęty w postaci wsparcia finansowego i infrastrukturalnego. Następnym priorytetem powinny być działania na rzecz ograniczenia uchodźstwa i nielegalnej emigracji do Europy przez Morze Śródziemne. Państwa NATO i UE przy ścisłej współpracy z ONZ i władzami państw regionu, w tym z GNA, muszą opracować i wdrożyć nową strategię walki z grupami przemytniczymi. Równocześnie wyżej wskazane podmioty powinny zwiększyć wysiłki ratownicze na Morzu Śródziemnym.

\section{Streszczenie}

Celem artykułu jest przedstawienie i ocena okoliczności zaangażowania się Wielkiej Brytanii w interwencję zbrojną w Libii w 2011 r. Omówiono w nim przyczyny włączenia się Wielkiej Brytanii w rozwiązanie kryzysu libijskiego, jej działania na rzecz legitymizacji polityki militarnej wobec Libii, wkład zbrojny w operację bojową oraz konsekwencje tych działań dla Libii i Wielkiej Brytanii. Główną tezą artykułu jest stwierdzenie, że decydując o udziale w operacji wojskowej w Libii, rząd Davida Camerona przede wszystkim kierował się przesłankami natury humanitarnej. Interesy narodowe Wielkiej Brytanii, głównie gospodarcze i w zakresie bezpieczeństwa, miały znaczenie drugorzędne. W artykule stwierdzono również, że Wielka Brytania nie była gotowa, aby wespół z Francją przewodzić działaniom zbrojnym w Libii. Jej władze chciały ograniczyć swoją odpowiedzialność za dowodzenie międzynarodowa koalicja, włączając w nie Stany Zjednoczone i Sojusz Północnoatlantycki. Wskazano również błędy popełnione przez Wielką Brytanię i międzynarodową koalicję, które przyczyniły się do rozwoju kryzysu w Libii po przeprowadzeniu interwencji zbrojnej. 


\section{Great Britain in the military intervention in Libya in 2011}

The purpose of the article is to present and assess the circumstances of Britain's engagement in a military intervention in Libya in 2011. It discusses the reasons for the UK's involvement in the solution of the Libyan crisis, its efforts to legitimize military policy towards Libya, its military contribution to combat operations and consequences of this actions for Libya and Great Britain. The main thesis of the article is that when deciding to participate in a military operation in Libya, David Cameron's government was primarily motivated by humanitarian reasons. The national interests of the United Kingdom, mainly economic and security, were secondary. The article also stated that Britain was not ready to lead with France the military actions in Libya. Its authorities wanted to limit their responsibility for commanding of the international coalition, engaging the United States and the North Atlantic Alliance. Also highlighted the mistakes made by the United Kingdom and the international coalition that contributed to the development of the Libyan crisis after the military intervention.

\section{Bibliografia}

Armbruster J., Arabska wiosna. Rewolucja w świecie islamskim, tłum. R. Kędzierski, Wrocław 2011.

Biscop S., The UK and European defence: leading or leaving?, „International Affairs” 2012, t. LXXXVIII, nr 6.

Brown D., Britain and the Politics of Counter-Terrorism: The 2002 New Chapter and Beyond, w: The Development of British Defence Policy. Blair, Brown and Beyond, red. D. Brown, London-New York 2010, s. 81-106.

Butalia B., The Assassin's Mace, Bloomington 2011.

Callaghan J., The Labour Party and Foreign Policy. A History, London-New York 2007.

Cawkwell T.W., UK Communication Strategies for Afghanistan, 2001-2014, London-New York 2016.

Dobson A.P., Anglo-American Relations in the Twentieth Century. Of friendship, conflict and the rise and decline of superpowers, London-New York 1995.

Dumbrell J., Personal diplomacy: Relations between prime ministers and presidents, w: Anglo-American Relations. Contemporary Perspectives, red. A.P. Dobson, S. Marsh, London-New York 2013, s. 82-104.

Gaskarth J., British Foreign Policy. Crises, Conflicts and Future Challenges, CambridgeMalden 2013.

Gowland D., Britain and the European Union, London-New York 2017.

Grzebyk P., Ramy prawne użycia sity, w: Bezpieczeństwo międzynarodowe, red. R. Kuźniar $\mathrm{i}$ in., Warszawa 2012, s. 120-142.

Hodge C., Britain and the Balkans. 1991 until the Present, London-New York 2006.

Kitchen V.M., The Globalization of NATO. Intervention, Security and Identity, London-New York 2010.

Marsh S., The Anglo-American defence relationship, w: Anglo-American Relations. Contemporary perspectives, red. A.P. Dobson, S. Marsh, London-New York 2013, s. 179-207.

Murray R.W., Humanitarianism, Responsibility or Rationality? Evaluating Intervention as State Strategy, w: Libya. The Responsibility to Protect and the Future of Humanitarian Intervention, red. A. Hehir, R. Murray, New York 2013, s. 15-33.

Phinney T.R., Airpower versus Terrorism. Three Case Studies, Montgomery 2003.

Rowe P., Legal Accountability and Britain's Wars 2000-2015, London-New York 2016. 
Sharp J.M., Tony Blain nurtures the special relationship, w: Why did the United States Invade Iraq?, red. J.K. Cramer, A.T. Thrall, London-New York 2012, s. 167-200.

Strong J., Public Opinion, Legitimacy and Tony Blair's War in Iraq, London-New York 2017.

Wall S., The Official History of Britain and the European Community, t. II: From Rejection to Referendum, 1963-1975, London-New York 2013.

Biog r a m: Lukasz Jureńczyk - dr hab., prof. UKW; pracuje w Instytucie Nauk Politycznych Uniwersytetu Kazimierza Wielkiego w Bydgoszczy. Specjalizuje się w międzynarodowych stosunkach politycznych i polityce bezpieczeństwa. Jest autorem monografii pt. Polska misja w Iraku. Implikacje dla Iraku i Polski (2010), Wojna z talibami i Al-Kaida. Afganistan $w$ latach 1994-2012 (2013), Polska misja $w$ Afganistanie. Wojsko Polskie $w$ operacji reagowania kryzysowego NATO (2016) i Polska w Sojuszu Pótnocnoatlantyckim. Wojsko Polskie w operacjach reagowania kryzysowego NATO (2016). E-m a il: lukaszjurenczyk@ukw.edu.pl. 